\title{
De Ontwerpregeling ter bescherming van derivatenbeleggers tegen faillissement van de tussenpersoon nader beschouwd
}

\author{
E.W. Kuijper
}

\section{Inleiding}

Afgelopen zomer heeft de minister een ontwerpregeling voor de bescherming van derivatenbeleggers ter consulatie voorgelegd. Het voorstel (hierna: de Ontwerpregeling) beoogt beleggers die handelen in derivaten via een bank, beleggingsonderneming of clearinginstelling, te beschermen tegen intermediary risk. De Ontwerpregeling maakt deel uit van de Wijzigingswet financiële markten 2016. ${ }^{1}$ In deze bijdrage beschouw ik de Ontwerpregeling nader. De bijdrage vangt aan met achtergrondinformatie over derivaten (par. 2). Voorts schets ik de aanleiding voor de Ontwerpregeling (par. 3) en haar essentie (par. 4) alvorens ik inga op onderdelen uit de Ontwerpregeling die de aandacht verdienen (par. 5). Deze bijdrage wordt afgesloten met de conclusie dat de Ontwerpregeling complex is en op onderdelen nog onduidelijk (par. 6). ${ }^{2}$

\section{Derivaten}

Derivaten zijn overeenkomsten die betrekking hebben op een onderliggende waarde. In deze bijdrage beperk ik mij tot derivaten met een financiële onderliggende waarden zoals aandelen, obligaties, valuta of indices. Alle derivaten, hoe complex ook, zijn te herleiden tot een van de drie hoofdvormen: termijnovereenkomsten, opties en swaps.

- Een termijnovereenkomst is vergelijkbaar met een kooptransactie onder opschortende tijdsbepaling waarbij overdracht en betaling plaatsvinden op een afgesproken toekomstig tijdstip (de expiratiedatum).

- In een optiecontract verkrijgt de koper (houder) tegen betaling van een premie aan de verkoper (schrijver) een (optie)recht tot koop (call-optie) of verkoop (put-optie) van een onderliggende waarde voor een afgesproken prijs gedurende een bepaalde periode ${ }^{3}$ (de looptijd) of op de expiratiedatum. ${ }^{4}$

1 Zie <wwwinternetconsultatienl/wijzigingswetfm2016>.

2 Deze bijdrage is gebaseerd op een reactie de auteur heeft ingezonden op het consultatiedocument. De auteur bedankt mr. J. Goossens voor zijn commentaar op een eerdere versie van deze bijdrage.

3 Optie Amerikaanse stijl.

4 Optie Europese stijl. 
- Partijen bij een swap komen overeen dat zij elkaar periodiek of eenmalig over en weer een geldsom betalen die gelijk is aan een (percentage van een) referentiewaarde. ${ }^{5}$

Bij financiële derivaten is het niet altijd de bedoeling dat de onderliggende waarde daadwerkelijk wordt geleverd (physical settlement). In plaats daarvan wordt het contract afgewikkeld doordat een der partijen het verschil betaalt tussen de afgesproken prijs en de marktprijs van de onderliggende waarde (cash settlement). Bij swaps worden de te betalen geldsommen verrekend (payment netting). Die vordering dan wel verplichting die voortvloeit uit het derivatencontract wordt de 'derivatenpositie' genoemd. ${ }^{6}$

Met derivaten kan men risico afdekken of juist aangaan. Wat het laatste betreft: door het tijdselement en de prijsfluctuaties van de onderliggende waarde kan met een relatief kleine inleg een groot negatief maar ook een groot positief resultaat worden geboekt. Professionele beleggers, zoals pensioenfondsen, beleggingsinstellingen, ondernemingen, overheden en financiële instellingen benaderen gebruikelijk een bank (dealer) om een derivaat aan te gaan op de onderhandse (over-the-counter, OTC) markt. Daarnaast worden gestandaardiseerde opties en termijncontracten ${ }^{7}$ verhandeld op de georganiseerde derivatenmarkt via beurzen en andere georganiseerde handelsplatformen. Daar kan ook de particuliere belegger terecht. Die zal een bank of beleggingsonderneming (broker) inschakelen die is aangesloten bij het handelssysteem ('trading member') om de transactie voor hem aan te gaan via de beurs. Beurstransacties worden gecleared door een clearingorganisatie die optreedt als centrale tegenpartij, ${ }^{8}$ wat inhoudt dat de clearingorganisatie de verplichtingen aan beide zijden van een transactie overneemt en nakoming daarvan garandeert. ${ }^{9}$ Ten gevolge van clearing komen twee derivatencontracten tot stand, een tussen de clearingorganisatie en de koper en een tussen de clearingorganisatie en de verkoper. Alleen partijen die aansluiting hebben bij het clearingsysteem ('clearing members') mogen met de clearingorganisatie contracteren. Dit kan de trading member zijn, maar omdat het clearinglidmaatschap vanwege de daaraan verbonden voorwaarden is voorbehouden aan kapitaal-

5 In het geval van een renteswap is dat een rentepercentage van een geleend bedrag (de notional amount), maar de betaling kan ook afhankelijk zijn van een toekomstig onzekere gebeurtenis zoals faillissement in het geval van een credit default swap. Zie over swaps P.M. Verhagen, Swaps, O\&F 2002/50, p. 84-89.

6 Zie voor meer uitleg over financiële derivaten J.H. Dalhuisen \& L.D. van Setten, Zekerheid in roerende zaken en rechten (Preadvies van de Vereeniging 'Handelsrecht'), Deventer: Kluwer 2003, p. 92-93.

7 Georganiseerd verhandelde termijncontracten worden aangeduid als futures en OTC-termijncontracten als forwards.

8 Clearing is een verzamelnaam voor verschillende administratieve processen die plaatsvinden na de totstandkoming van een derivatencontract, maar voor de afwikkeling daarvan. Zie voor meer informatie over clearing B.J.A. Zebregs, Effecten- en derivatenclearing, Amsterdam: NIBE-SVV 2013 en L.J. Silverentand \& P. Heemskerk, Clearing: kern- en knelpunten, in: S.E. Bartels, A.J. Verdaas \& R.J. van der Weijden (red.), Effecten en vermogensrecht, Deventer: Kluwer 2011, p. 242 e.v.

9 Dit geschiedt via novatie of een open offer structuur, zie Zebregs 2013, p. 36-51 en Silverentand \& Heemskerk 2011, p. 242 e.v. 
krachtige ondernemingen (banken), zal de trading member voor clearing dikwijls een derde inschakelen.

\section{Aanleiding Ontwerpregeling}

Het faillissement van Van der Hoop Bankiers eind 2005 maakte duidelijk dat derivatenposities, ${ }^{10}$ die een bank tot stand brengt voor rekening van cliënten, niet zijn afgescheiden van het vermogen van de bank. Cliënten hebben slechts een concurrente vordering op hun bank ten aanzien van derivatenposities en de baten die voortvloeien uit de afwikkeling daarvan. ${ }^{11}$ Dit in tegenstelling tot effectenbezitters, wier aanspraken zijn beschermd door de Wet giraal effectenverkeer (Wge). Bescherming is naast wenselijk ook vereist door de Markets in Financial Instruments Directive 2004/39 (MiFID). ${ }^{12}$ Deze richtlijn verlangt dat een (bank-) beleggingsonderneming die 'financiële instrumenten aanhoudt die aan een cliënt toebehoren', waaronder derivaten, ${ }^{13}$ adequate regelingen treft 'ter vrijwaring van de eigendomsrechten van de cliënt, met name in het geval van insolventie van de onderneming. ${ }^{14}$ De eis is overgenomen in art. 4:87 Wet op het financieel toezicht (Wft). Wanneer het gaat om derivaten, weten Nederlandse banken niet hoe invulling te geven aan deze eis. Volgens de minister en de Autoriteit Financiële Markten kan bescherming alleen worden gerealiseerd door middel van een wetswijziging. ${ }^{15}$ Een eerdere poging het onderwerp te regelen in de Wge in 2007 is op niets uitgelopen.

Inmiddels is de Ontwerpregeling geconsulteerd. Ditmaal wordt niet alleen rekening gehouden met de MiFID maar ook met de bepalingen uit de European Markets Infrastructure Regulation no. 648/2012 (EMIR). Op grond van de EMIR moeten bepaalde categorieën OTC-derivaten centraal worden gecleared. De EMIR vereist dat clearingorganisaties procedures in werking hebben om bij faillissement van een clearing member de derivatenposities die de clearing member aanhoudt voor rekening van cliënten over te dragen aan een andere, solvente clearing member. ${ }^{16}$ Bij haar vergunningaanvraag moet een clearingorganisatie kunnen verifiëren dat zij onder nationaal recht overdracht kan realiseren. ${ }^{17}$ Omdat overdracht van posities bij faillissement van een Nederlandse clearing member strijd

10 Bij Van der Hoop betrof het posities in beursverhandelde opties en futures.

11 De oorzaak is gelegen in het feit dat de bank derivatentransacties aangaat in eigen naam voor rekening en risico van de cliënt in de zin van art. 7:414 BW (lastgeving in eigen naam). De bank wordt beschouwd als rechthebbende van de positie die ontstaat door clearing van de beurstransactie. Representeert de positie een vordering tot betaling van een geldsom, dan heeft de cliënt een gelijkluidende vordering op de bank tot doorlevering van die geldsom. In het geval van Van der Hoop werd een beroep op art. 7:420 lid 1 BW door cliënten geblokkeerd door de clearing member van Van der Hoop.

12 De MiFID is vervangen door Richtlijn 2014/65/EU (MiFID II) die in juli 2016 moet zijn geïmplementeerd in het nationale recht.

13 Zie bijlage 1 , deel $C$, punt $4 \mathrm{t} / \mathrm{m} 10 \mathrm{MiFID}$.

14 Art. 13 lid 7 MiFID (art. 16 lid 8 MiFID II).

15 Zie Kamerstukken 2005/06, 30300 IXB, 22, p. 7.

16 Art. 48 lid 5 en 6 EMIR.

17 Art. 48 lid 4 EMIR. 
oplevert met art. 23 en 35 Faillissementswet (Fw), zou daarvoor medewerking zijn vereist van de curator. Dit kan problemen opleveren voor de clearingorganisatie. De Ontwerpregeling beoogt het Nederlandse recht in lijn te brengen met de EMIR en te bereiken dat de clearingprocedures ook bij faillissement van een (Nederlandse) clearing member afdwingbaar zijn. ${ }^{18}$

\section{Essentie Ontwerpregeling}

De Ontwerpregeling gaat ervan uit dat bij de uitvoering van een order in derivaten altijd een derivatencontract tot stand komt tussen de cliënt en diens 'tussenpersoon'19 (in de Ontwerpregeling: de 'cliëntpositie'20) en een spiegelbeeldig contract tussen laatstgenoemde en een 'derde' (in de Ontwerpregeling: de 'corresponderende positie'21). De essentie van de regeling is dat de corresponderende posities, evenals de rechten en verplichtingen met betrekking tot het stellen van zekerheid, een 'afgescheiden vermogen' (het 'derivatenvermogen'22) vormen. Zo dient bij faillissement te worden voorkomen dat 'corresponderende posities', en de baten die daaruit voortvloeien bij afwikkeling, onder het faillissementsbeslag vallen. Het afgescheiden vermogen zou tevens vermogensrechtelijke basis bieden om die posities, en de in verband daarmee gestelde zekerheden, zonder complicaties te kunnen overdragen aan een andere tussenpersoon. De Ontwerp-MvT belicht met name het scenario waarin posities en zekerheden wor-

18 Omdat de EMIR als verordening directe werking heeft, kan worden betwist of een wetswijziging noodzakelijk is. Dat een wetswijziging ten minste wenselijk is om een eind te maken aan onduidelijkheid inzake de verhouding tussen de EMIR en het Nederlandse goederen- en faillissementsrecht, blijkt uit W.A.K. Rank, Segregatie en portabiliteit: de Wge als panacee voor MiFID en EMIR, MvV 2014, nr. 7/8, p. 219-220.

19 Art. 49f sub g Ontwerpregeling definieert de tussenpersoon als een 'beleggingsonderneming, bank of clearinginstelling als bedoeld in art. 1:1 van de Wet op het financieel toezicht, waaraan het op grond van die wet is toegestaan beleggingsdiensten te verlenen onderscheidenlijk het bedrijf van bank of clearinginstelling uit te oefenen, die voor rekening en risico van haar cliënten corresponderende posities aangaat'.

20 Art. 49f sub c Ontwerpregeling definieert cliëntpositie als een 'derivatenpositie die een cliënt aangaat met een tussenpersoon'.

21 Art. 49f sub d Ontwerpregeling definieert corresponderende positie als 'de derivatenpositie die een tussenpersoon met een derde is aangegaan in verband met het aangaan van een cliëntpositie, en die overeenkomt met de betreffende cliëntpositie'.

22 Art. 49f sub f Ontwerpregeling definieert derivatenvermogen als een 'afgescheiden deel van het vermogen van een tussenpersoon waartoe alle corresponderende posities behoren alsmede alle rechten en verplichtingen met betrekking tot het stellen van zekerheid ten behoeve van corresponderende posities, en dat uitsluitend dient tot voldoening van vorderingen die voortvloeien uit de met de corresponderende posities samenhangende cliëntposities'. 
den overgedragen. Over de gevolgen van een situatie waarin overdracht om welke reden dan ook niet (tijdig) slaagt, ${ }^{23}$ wordt nauwelijks uitgeweid.

\section{Aandachtspunten}

Hoewel ook andere mechanismen denkbaar zijn om de door Europa vereiste bescherming te realiseren, ben ik van mening dat een afgescheiden vermogen kan dienen als vermogensrechtelijke basis om enerzijds derivatenposities die een tussenpersoon aangaat voor cliënten in faillissement over te dragen aan een andere tussenpersoon en anderzijds bij beëindiging van posities de baten die daaruit voortvloeien te reserveren voor de voldoening van vorderingen van cliënten. Dat neemt niet weg dat de voorgestelde regeling op punten nadere overdenking behoeft. Hieronder volgt een aantal aandachtspunten.

\subsection{Plaats regeling}

De regeling is uitgewerkt in de nieuw voorgestelde art. $49 \mathrm{f}$ tot en met $49 \mathrm{~h}$ Wge. Volgens de minister ligt de Wge voor de hand omdat parallellen zijn te trekken tussen de intermediair bij effecten en de tussenpersoon bij derivaten. ${ }^{24}$ Deze mening deel ik niet. Doel van de Wge is immers het regelen van de girale afwikkeling van effectentransacties, waaronder het leveren en verpanden van girale effecten. De Wge regelt derhalve meer dan alleen de bescherming van de aanspraken van de belegger tegen faillissementsrisico. Derivaten zijn geen effecten in de zin van de Wge en de regeling stelt ook niet voor derivaten op te nemen in het Wgesysteem. Voorkomen moet worden dat beleggers en tussenpersonen derivaten gaan beschouwen als girale effecten. Bovendien, zoals de minister aangeeft, berust de Ontwerpregeling op een wezenlijk andere vorm van vermogensscheiding dan het Wge-systeem. Het voorgestelde beschermingsmechanisme berust op een constructie waarbij de tussenpersoon rechthebbende is op het derivatenvermogen, terwijl de Wge de effectenbezitter deelgerechtigd maakt in een bijzondere (effecten)gemeenschap. Ook in dit opzicht past de Ontwerpregeling niet in de Wge. Een regeling ter bescherming van derivatenbeleggers is beter op haar plaats in de Wft en/of de Fw. ${ }^{25}$ In dit licht wijs ik erop dat goederenrechtelijke bepalingen in een wet met een voornamelijk publiekrechtelijk karakter geen

23 De kans dat overdracht niet slaagt, bijvoorbeeld om redenen van risicobeheer, is aanwezig. Bovendien is de ontvangende clearing member alleen verplicht posities te aanvaarden indien hij daartoe vooraf een overeenkomst met cliënten heeft gesloten, zie art. 48 lid 5 en 6 EMIR. Uit voornoemd artikel blijkt ook dat de EMIR rekening houdt met de mogelijkheid dat overdracht niet slaagt. Vgl. B.J.A. Zebregs, Guaranteed Portability under EMIR? Several hurdles remain to be cleared, JIBFL 2011, vol. 26, nr. 5, p. 276-279.

24 Ontwerp-MvT, p. 6: 'Zo vormen beiden slechts een tussenschakel in de keten van een effect respectievelijk derivaat en treden zij beiden op voor rekening en risico van hun cliënt.'

25 De Wft bevat reeds bepalingen ter regulering van (de dienstverlening van) banken, beleggingsondernemingen en clearinginstellingen en bovendien zijn in die wet en lagere regelgeving art. 13 lid 7 MiFID en bijbehorende implementatiebepalingen geïmplementeerd. 
noviteit zijn. Denk bijvoorbeeld aan de vermogensscheidingsregeling voor beleggingsinstellingen uit art. 4:37j Wft. ${ }^{26}$

\subsection{Reikwijdte regeling}

Uit de Ontwerp-MvT blijkt dat de Ontwerpregeling beleggers beoogt te beschermen ongeacht de manier waarop het derivaat wordt verhandeld en ongeacht het orderuitvoeringsbeleid dat de bank of de beleggingsonderneming hanteert, ${ }^{27}$ zolang zij maar optreedt als 'tussenpersoon'. Dat is het geval als zij 'voor rekening en risico van haar cliënten corresponderende posities' aangaat. ${ }^{28}$ Door de gekozen opzet is de reikwijdte van de Ontwerpregeling echter onduidelijk. ${ }^{29}$ De definities sluiten niet aan bij de diverse orderuitvoeringsmodellen die de praktijk hanteert, waardoor de Ontwerpregeling noch op de OTC-derivatenhandel noch op de georganiseerde handel van toepassing lijkt. Hieronder volgt nadere uitleg daarover. Gemakshalve wordt daarbij steeds uitgegaan van een situatie waarin de belegger een bank inschakelt die de functie van trading member en clearing member in zich verenigt.

\subsubsection{Orderuitvoeringsmodellen}

Banken kunnen bij het uitvoeren van orders optreden als lasthebber van de cliënt en/of als tegenpartij. De hoedanigheid hangt onder meer af van de manier waarop het derivaat wordt verhandeld, onderhands of via een georganiseerd handelsplatform, en van de vraag of het derivaat al dan niet centraal wordt gecleared. De Ontwerpregeling gaat uit van een orderuitvoeringsmodel waarbij zowel tussen de cliënt en de tussenpersoon als tussen laatstgenoemde en een derde ${ }^{30}$ back-to-back een derivatenpositie tot stand komt. Deze opzet sluit aan bij het matched principal model (ook wel riskless principal model genoemd) dat banken hanteren in de OTC-derivatenhandel. Volgens dit model gaat de bank voor eigen rekening een derivatentransactie aan met de cliënt, welke transactie wordt gedocumenteerd in een derivatencontract. ${ }^{31}$ Noemenswaardig is dat de bank bij het aangaan van de transactie met zijn cliënt tevens een order voor rekening van zijn cliënt

30 Dit kan blijkens het voorbeeld op p. 43 Ontwerp-MvT tevens een andere cliënt zijn.

31 Daarvoor worden de standaardvoorwaarden van de International Swaps and Derivatives Association (ISDA) gebruikt of daarvan afgeleide (eigen) documentatie. Zie voor meer informatie over het gebruik van de ISDA-documentatie onder meer C.H. Schot, To hedge or not to hedge; de toekomst van de derivatenmarkt, O\&F 2012/2, p. 39-52 en M. Peeters, OTC-derivaten, beurs-effecten en risico's, O\&F 2005/67, p. 63-77. 
uitvoert. $^{32}$ Bij het aangaan van de spiegelbeeldige transactie met een derde, handelt de bank niet voor rekening van haar cliënt, maar voor eigen rekening.

\section{Matched principal model}

De bank voert een order van een cliënt uit door zelf met die cliënt een derivatentransactie aan te gaan en tegelijkertijd, of vooraf, back-to-back een spiegelbeeldige transactie te sluiten met een andere cliënt of een derde in de markt (zie figuur 1). De bank wordt de koper tegenover de verkoper en andersom de verkoper tegenover de koper. Beide transacties worden gedocumenteerd in een derivatencontract. Hoewel de bank beide contracten aangaat als principaal en het tegenpartijrisico op zich neemt, loopt zij geen commercieel risico omdat de rechten dan wel verplichtingen jegens haar beide tegenpartijen tegen elkaar wegvallen.

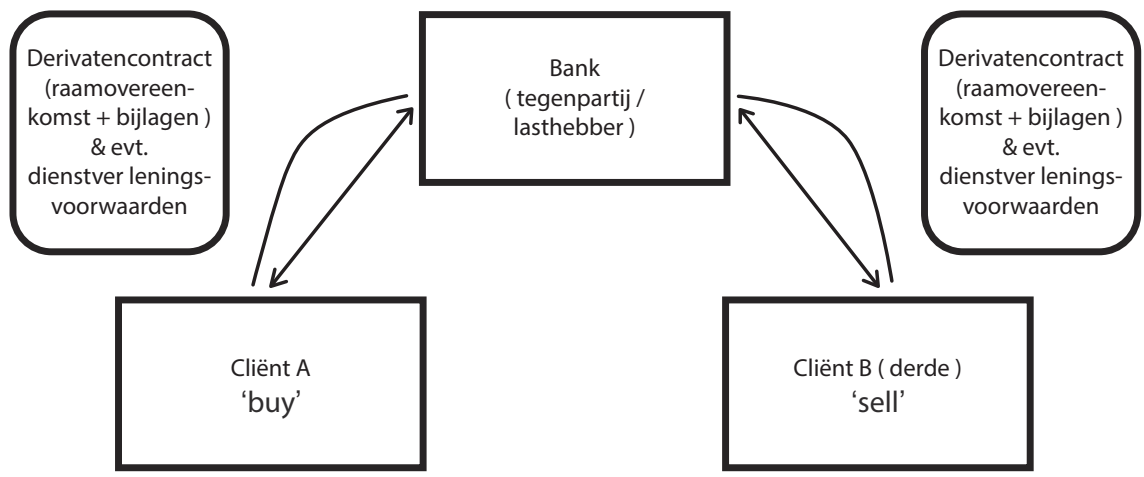

Figuur 1: Matched principal model

In het lastgevingsmodel gaat de bank als lasthebber de derivatentransactie aan via het handelsplatform. Ten gevolge van het clearingproces komt een derivatencontract tot stand tussen de clearingorganisatie en de bank (hier tevens clearing member). Tussen de bank en de cliënt komt geen derivatencontract tot stand. De cliënt ontleent een recht op doorlevering aan de dienstverleningsovereenkomst.

32 Dit is mogelijk op basis van Selbsteintritt in de zin van art. 7:416 BW, zie S.B. van Baalen, Zorgplichten in de effectenhandel (diss. Groningen), Deventer: Kluwer 2006, p. 325. In overweging 24 preambule MiFID II is opgenomen: 'Dealing on own account when executing client orders should include firms executing orders from different clients by matching them on a matched principal basis (back-to-back trading), which should be regarded as acting as principal and should be subject to the provisions of the Directive covering both the execution of orders on behalf of clients and dealing on own account.' 


\section{Lastgevingsmodel}

De bank leidt de order van de cliënt door naar een georganiseerd handelsplatform waar, na koppeling van de order aan een tegenliggende order, een derivatentransactie tot stand komt. Die transactie wordt opgegeven voor clearing bij een clearingorganisatie waarna twee derivatencontracten tot stand komen (zie figuur 2). De bank houdt de derivatenpositie, die tot stand komt ten gevolge van het clearingproces van de transactie ter beurze, aan bij de clearingorganisatie in eigen naam voor rekening en risico van de cliënt.

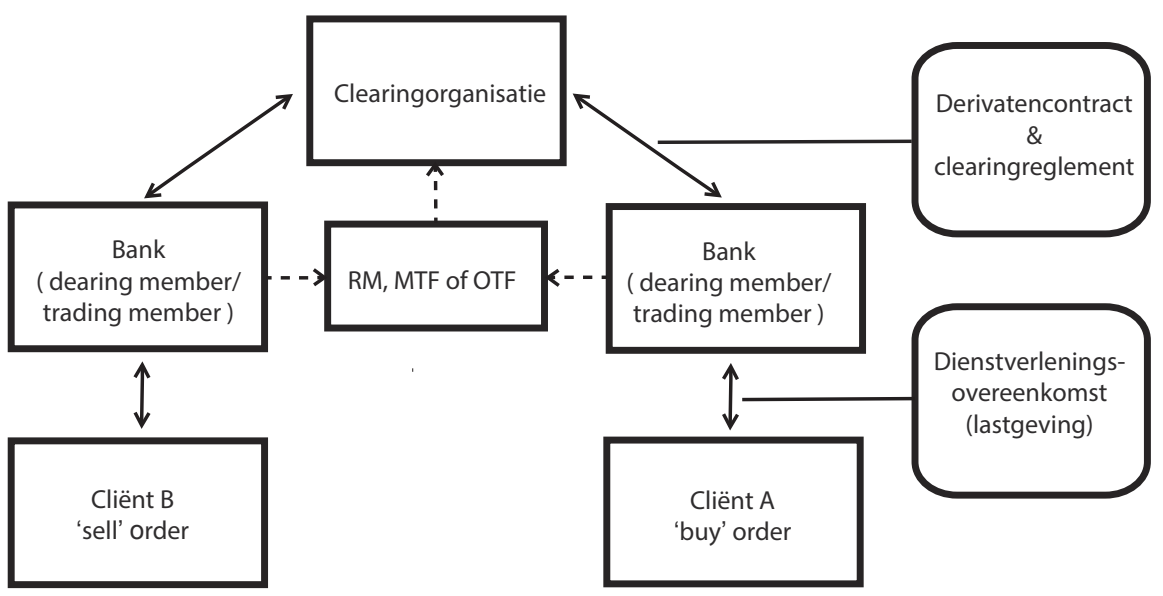

Figuur 2: Lastgevingsmodel

\subsubsection{Aansluiting bij de verschillende handelsmodellen}

Uit bovenstaande blijkt dat het belangrijkste verschil tussen het matched principal model en het lastgevingsmodel is dat onder eerstgenoemd model de bank optreedt als directe tegenpartij van de cliënt, terwijl dat onder laatstgenoemd model niet het geval is. Van een 'corresponderende positie' in de zin van de Ontwerpregeling is in het lastgevingsmodel geen sprake, noch van een 'cliëntpositie'. De enige positie die kan worden geïdentificeerd, is de positie die tot stand komt tussen de bank en de clearingorganisatie naar aanleiding van de transactie die de bank ter beurze is aangegaan voor rekening van de cliënt. De definities van de Ontwerpregeling sluiten niet aan bij het orderuitvoeringsmodel dat uitsluitend is gebaseerd op lastgeving. Beleggers in georganiseerd verhandelde derivaten lijken daardoor buiten de boot te vallen.

Verwarring ontstaat ook doordat slechts als tussenpersoon wordt aangemerkt, zij die 'voor rekening en risico van de cliënt corresponderende posities aangaat' met 
derden. ${ }^{33}$ Als opgemerkt handelt een bank die een OTC-derivatencontract tegensluit in de markt, en die daarmee een corresponderende positie aangaat met een derde in de zin van de Ontwerpregeling, voor eigen rekening. Indien de passage 'voor rekening en risico van' moet worden opgevat als 'voor rekening van' in de zin van art. 7:414 lid 1 BW, dan kan de bank niet worden aangemerkt als tussenpersoon. Dat zou betekenen dat beleggers in OTC-derivaten ook geen bescherming ontlenen aan de regeling en dat kan niet de bedoeling zijn.

De minister maakt het zichzelf moeilijk door in enkele definities, die in samenhang moeten worden gelezen, zowel de OTC- als de beurshandel te willen vangen. Voor het doel van de Ontwerpregeling, het beschermen van beleggers tegen intermediary risk (en niet tegen het tegenpartijisico), is voldoende de reikwijdte van de regeling te beperken tot derivatenposities die een bank, beleggingsonderneming of clearinginstelling aangaat met (of tot stand doet brengen door) een derde voor rekening en risico een cliënt. ${ }^{34}$ Die posities, die kunnen worden gedefinieerd als cliëntenposities, vormen het afgescheiden vermogen en dienen tot verhaal van vorderingen van cliënten op grond van wier order een cliëntenpositie tot stand is gebracht. $^{35}$

\subsubsection{Aansluiting bij ontwikkelingen in het kader van MiFID II}

De dienstverlening in OTC-derivaten is vanwege de EMIR volop in beweging. Het is de vraag of marktpartijen orders in clearingplichtige OTC-derivaten in de toekomst zullen blijven uitvoeren op back-to-back basis. MiFID II vereist namelijk dat clearingplichtige OTC-derivaten worden verhandeld via een georganiseerd handelsplatform. ${ }^{36}$ Banken die orders in clearingplichtige OTC-derivaten uitvoeren door middel van matched principal trading, worden niet aangemerkt als georganiseerd handelsplatform in de zin van MiFID II. ${ }^{37}$ Orders in dergelijke derivaten zullen daarom via een apart georganiseerd handelsplatform moeten worden geleid. De verwachting is dat banken hun infrastructuur voor de orderuitvoering en clearing van clearingplichtige OTC-derivaten zullen herzien en dat deze meer gaat lijken op die van (geclearede) beursverhandelde derivaten. ${ }^{38}$ Denkbaar is dat banken naast de operationele processen ook het handelsmodel voor georganiseerd verhandelde derivaten zullen nabootsen. In dat geval zou de Ontwerpregeling niet aansluiten bij de handel in geclearede OTC-derivaten.

33 Voor een toelichting bij de definitie van tussenpersoon zie Ontwerp-MvT, p. 42.

34 Daarbij verwijst de term 'voor rekening en risico' naar art. 7:414 BW.

35 Feitelijk zullen dat posities zijn die tot stand komen door clearing.

36 Dit kan zijn een gereglementeerde markt (RM), een multilaterale handelsfaciliteit (MTF) of een georganiseerde handelsfaciliteit (OTF) in de zin van art. 4 sub 21 t/m 23 MiFID II.

37 Handelsplatformen mogen orders in clearingplichtige derivaten immers niet bijeenbrengen op basis van matched principal trading omdat zij daarbij (tevens) handelen voor eigen rekening, zie art. 19 lid 5, 20 lid 2 en 47 lid 2 MiFID II.

38 Zie bijvoorbeeld S. Grob, You only Live Twice, Creating the FCM of the future, Fidessa 2013 en R. Devai, OTC derivatives, systemic risk and market structure, Wfe Focus 2011, nr. 215, p. 3. 


\subsection{Afgescheiden vermogen}

Het beschermingsmechanisme bestaat uit een 'afgescheiden vermogen'. ${ }^{39}$ Wat bedoelt de minister daarmee? De wetgever is terughoudend met het gebruik van de term afgescheiden vermogen in wettelijke bepalingen. ${ }^{40}$ In de rechtsliteratuur is de term gereserveerd voor goederen die binnen het vermogen van een rechtssubject uitsluitend vatbaar zijn voor verhaal door crediteuren wier vordering betrekking heeft op (een van) die goederen. Bij faillissement van de schuldenaar blijven de goederen buiten het faillissementsbeslag. Vooralsnog kent ons recht geen algemene wettelijke regeling voor het afgescheiden vermogen. Om verwarring te voorkomen, dient het gebruik van de term gepaard te gaan met een heldere definitie en toelichting zodat geen twijfel kan ontstaan over de daaraan verbonden rechtsgevolgen. In het geval van het derivatenvermogen ontbreekt een definitie of toelichting bij de term afgescheiden (deel van het) vermogen. Wel zijn er aanwijzingen dat het derivatenvermogen beschikt over de kenmerken die de rechtsliteratuur toedicht aan een afgescheiden vermogen. Zo is het derivatenvermogen 'een afgescheiden deel van het vermogen van een tussenpersoon (...) dat uitsluitend dient tot voldoening van vorderingen die voortvloeien uit de met de corresponderende posities samenhangende cliëntposities' ${ }^{41}$ [curs. EWK] en dat 'in geval van faillissement buiten de boedel blijft'. ${ }^{42}$ Bij faillissement van de tussenpersoon is de Fw niet van toepassing op het derivatenvermogen. ${ }^{43}$

Merkwaardig is dat hoewel de Fw niet van toepassing is, de curator van de tussenpersoon bij faillissement (eind)verantwoordelijk is voor het 'beheer' van het derivatenvermogen. ${ }^{44}$ Welke bevoegdheden heeft de curator met betrekking tot het derivatenvermogen als de Fw niet van toepassing is? Bovendien, waar worden de kosten die gepaard gaan met het 'beheer' van het derivatenvermogen uit voldaan? Valt het derivatenvermogen dan toch onder het faillissementsbeslag?

\subsection{Bescherming van zekerheden}

De clearingorganisatie verlangt dat clearing members zekerheden ${ }^{45}$ stellen ter afdekking van verplichtingen die voortvloeien uit derivatencontracten. ${ }^{46}$ Op zijn

Ontwerp-MvT, p. 42: '(...) het aangaan van derivatenposities door een bank, beleggingsonderneming of clearinginstelling die optreedt in de hoedanigheid tussenpersoon resulteert in een afgescheiden vermogen'.

40 De term wordt incidenteel gebruikt, bijvoorbeeld in de vermogensscheidingsregeling voor beleggingsinstellingen uit art. 4:37j Wft.

41 Art. $49 \mathrm{f}$ sub f Ontwerpregeling.

42 Ontwerp-MvT, p. 8.

43 Ontwerp-MvT, p. 41: 'Dientengevolge is bij insolventie van de tussenpersoon hetgeen is bepaald in de Faillissementswet niet van toepassing op de rechten en verplichtingen die behoren tot het derivatenvermogen, evenals de rechten en verplichtingen die voortvloeien uit de daarmee samenhangende cliëntposities.'

44 Art. 49h Ontwerpregeling en Ontwerp-MvT, p. 45, 46 en 51.

45 Met de term zekerheden doel ik in deze bijdrage niet alleen op zekerheidsrechten, maar ook op (te gelde gemaakte) zekerheidsobjecten.

46 Daartoe gaat de clearing member met de clearingorganisatie een financiëlezekerheidsovereenkomst aan tot overdracht of tot vestiging van een pandrecht met gebruiksrecht of wordt een (centrale) bankgarantie afgegeven. 
beurt verlangt de clearing member zekerheden van zijn cliënten. ${ }^{47}$ Hoewel het stellen van zekerheden een essentieel onderdeel is van de dienstverlening in derivaten, staan de afspraken die daarover worden gemaakt los van het derivatencontract. Het gaat om een voorwaarde voor dienstverlening: zonder zekerheden geen derivaat. Overdracht van posities bij faillissement van een clearing member heeft derhalve slechts zin wanneer het ontvangende clearing member over voldoende zekerheden beschikt om de posities na overdracht in stand te houden. Om die reden vereist art. 48 EMIR dat bij overdracht van posities ook de 'activa'48 die worden aangehouden in verband met die posities worden overgeboekt naar de ontvangende clearing member. ${ }^{49}$ Blijft de clearingorganisatie na afwikkeling van de derivatenposities 'een bedrag verschuldigd', dan dient zij dat bedrag te retourneren aan de clearing member of rechtstreeks aan cliënten, indien laatstgenoemden bij haar bekend zijn. ${ }^{50}$

In de praktijk neemt de clearing member de verplichting tot het stellen van zekerheden om operationele en commerciële redenen voor eigen rekening en verschaft de zekerheden uit eigen middelen. ${ }^{51}$ De vordering jegens de clearingorganisatie tot vrijgave of retournering van (resterende) zekerheden maakt deel uit van het vermogen van de clearing member. Onder huidig recht zou daarom voor de retournering (vrijgave) van zekerheden door de clearingorganisatie aan cliënten medewerking vereist zijn van de curator. ${ }^{52}$

De minister probeert tegemoet te komen aan de EMIR door naast de posities ook de rechten en verplichtingen met betrekking tot het stellen van zekerheden onderdeel te maken van het afgescheiden derivatenvermogen. ${ }^{53}$ Daarmee wordt weliswaar bereikt dat zekerheden die de clearing member de clearingorganisatie verschaft bij faillissement tezamen met de posities kunnen worden overgedragen aan een ander clearing member, maar onduidelijk is wat de gevolgen zijn indien overdracht van posities niet slaagt. Uit de definitie van 'derivatenvermogen' volgt

47 Daartoe vestigt een niet-professionele cliënt een pandrecht op alle goederen die de bank van de cliënt onder zich heeft dat tot zekerheid dient van 'al hetgeen de bank op enig moment, uit welken hoofde ook, van hem te vorderen heeft of verkrijgt' (zie art. 24 ABV 2009). Met professionele cliënten gaat de bank een financiëlezekerheidsovereenkomst aan tot vestiging van een pandrecht met gebruiksrecht in de zin van art. 7:51 sub c BW.

48 Art. 39 lid 10 EMIR: 'Onder "activa” wordt een zekerheid verstaan die ter dekking van posities wordt aangehouden; hieronder is het recht op overdracht van activa die gelijkwaardig zijn aan die zekerheid of de opbrengst van om het even welke te gelde gemaakte zekerheid begrepen, maar niet de bijdragen in het wanbetalingsfonds.'

49 Om te voorkomen dat de cliënt voor een tweede maal zekerheden zou moeten stellen.

50 Art. 48 lid 7 EMIR.

51 De EMIR staat niet in de weg aan deze praktijk. Zelfs wanneer de cliënt en de clearing member individuele segregatie zijn overeengekomen, meen ik dat, in tegenstelling tot de minister op p. 47 en 50 Ontwerp-MvT, de tussenpersoon niet verplicht is het onderpand dat de cliënt hem verschaft door te geleiden naar de clearingorganisatie, maar alleen de (bruto)waarde daarvan (ongeacht uit wiens vermogen dat afkomstig is). Dat is slechts anders indien tussenpersoon en cliënt fysieke segregatie zijn overeengekomen.

52 Het onttrekken van deze goederen aan de boedel zou benadeling opleveren van crediteuren en strijd met art. 35 Fw.

53 Het gaat hier om de rechten en verplichtingen van de tussenpersoon (clearing member) jegens de derde (clearingorganisatie). 
dat daarop uitsluitend vorderingen uit hoofde van 'cliëntposities' kunnen worden verhaald. Die vorderingen zouden in theorie volledig moeten kunnen worden voldaan uit de baten die voortvloeien uit de 'corresponderende posities' die deel uitmaken van het derivatenvermogen. Als na afwikkeling van alle posities derivatenvermogen resteert doordat de clearingorganisatie zekerheden vrijgeeft, wie kan zich daarop dan verhalen? De Ontwerpregeling geeft geen duidelijk antwoord. Uit de toelichting bij art. $49 \mathrm{~h}$ lid 4 Ontwerpregeling, ${ }^{54}$ welke bepaling regelt hoe het surplus moet worden verdeeld, is op te maken dat uitsluitend cliënten wier effecten deel zijn gaan uitmaken van het vermogen van de tussenpersoon op grond van een financiëlezekerheidsovereenkomst ${ }^{55}$ aanspraak maken op uitkering van het surplus, althans voor zover de tussenpersoon die effecten heeft gebruikt voor het stellen van zekerheid bij de clearingorganisatie. De minister gaat er kennelijk van uit dat de tussenpersoon de zekerheden die de cliënt hem verschaft een-op-een doorzet naar de clearingorganisatie. Omdat dit meestal niet het geval is, ${ }^{56}$ vraag ik mij af hoe deze regeling gaat uitwerken in de praktijk. Ten aanzien van zekerheid verschaft in de vorm van (een pandrecht op) giraal tegoed heeft de cliënt overigens, evenals onder huidig recht, slechts een concurrente vordering op de boedel..$^{57}$

Daarnaast is het onderbrengen van de rechten en verplichtingen met betrekking tot het stellen van zekerheden ten behoeve van 'corresponderende posities' in het derivatenvermogen geen fraaie oplossing omdat de clearing member de verplichting tot zekerheidsstelling voor eigen rekening neemt. Bedoelde rechten en verplichtingen zouden in een going concern situatie moeten worden gerekend tot het vermogen van de tussenpersoon dat niet bestaat uit derivatenvermogen. ${ }^{58}$ Bovendien vereist de EMIR slechts bescherming in een faillissementssituatie. Als alternatief beschermingsmechanisme kan worden gedacht aan een uitzonderingsbepaling in de $\mathrm{Fw}$ op grond waarvan de clearingprocedures voorrang hebben boven het faillissementsrecht. Zoals de minister aangeeft, heeft zowel Engeland, Duitsland als Frankrijk een dergelijke uitzonderingsbepaling opgenomen in zijn faillissementsrecht. ${ }^{59}$ Met een dergelijke bepaling zouden praktische en vermo-

54 Ontwerp-MvT, p. 48.

55 Dit is het geval bij een financiëlezekerheidsovereenkomst tot overdracht, maar ook bij een financiëlezekerheidsovereenkomst tot vestiging van een pandrecht waar de tussenpersoon zich onderpand in de vorm van effecten heeft toegeëigend op grond van een 'gebruiksrecht'. Cliënten die de tussenpersoon zekerheid verschaffen door middel van vestiging van een ('gewoon') pandrecht, kunnen geen beroep doen op de omslagregeling, zie Ontwerp-MvT, p. 48.

56 Als opgemerkt: tenzij de cliënt en de tussenpersoon fysieke segregatie zijn overeengekomen, verstrekt de tussenpersoon zekerheden uit eigen middelen. De zekerheden die de cliënt de tussenpersoon verschaft, dienen bovendien niet alleen ter afdekking van verplichtingen uit hoofde van derivatendienstverlening, maar ter afdekking van verplichtingen uit hoofde van het totaalpakket aan diensten dat de tussenpersoon de cliënt verleent.

57 En indien aan de voorwaarden is voldaan aanspraak op een uitkering onder het depositogarantiestelsel.

58 Ik vraag mij af of het onderbrengen van de rechten en verplichtingen met betrekking tot zekerheidsstelling in het derivatenvermogen geen onvoorziene gevolgen meebrengt, denk bijvoorbeeld aan de mogelijkheid voor de tussenpersoon die rechten en verplichtingen te verrekenen of te salderen met rechten en verplichtingen uit andere hoofde. 
gensrechtelijke vraagstukken, zowel ten aanzien van de bescherming van zekerheden als van posities, kunnen worden omzeild.

\section{Conclusie}

Door invoering van een afgescheiden 'derivatenvermogen' in de Wge beoogt de minister de Nederlandse wetgeving in lijn te brengen met de eisen die de MiFID en de EMIR stellen aan de bescherming van derivatenbeleggers. Hoewel ik de potentie onderschrijf van een afgescheiden vermogen als mechanisme om de gewenste en vereiste bescherming te realiseren, betwijfel ik de effectiviteit van de geconsulteerde regeling. De definities in de Ontwerpregeling slagen er niet in de praktijk te vangen, wat misschien wel de bron is van de gesignaleerde complexiteit van de regeling. Specifieke aandachtspunten zijn dat invoering van de Ontwerpregeling in de Wge verwarring kan veroorzaken, dat de reikwijdte niet helder is afgebakend, dat de rechtsgevolgen van het aanmerken van het derivatenvermogen als afgescheiden vermogen vaag zijn en dat het de vraag is of het voorgestelde derivatenvermogen ook uitkomst biedt ten aanzien van gestelde zekerheden. Aansluiting bij de praktijk en omzeiling van vermogensrechtelijke vraagstukken zou overigens kunnen worden gerealiseerd door een uitzonderingsbepaling op te nemen in de $\mathrm{Fw}$ op grond waarvan de clearingprocedures bij faillissement van een tussenpersoon voorrang hebben boven het nationale recht zoals omringende landen dat hebben gedaan. Beter ten halve gekeerd dan ten hele gedwaald, luidt de boodschap. 